\title{
Nine karyomorphs for spiny rats of the genus Proechimys (Echimyidae, Rodentia) from North and Central Brazil
}

\author{
Taís Machado ${ }^{1}$, Maria José de J. Silva ${ }^{1,2}$, Emygdia Rosa Leal-Mesquita ${ }^{3}$, Ana Paula Carmignotto ${ }^{4}$ \\ and Yatiyo Yonenaga-Yassuda ${ }^{1}$ \\ ${ }^{1}$ Universidade de São Paulo, Instituto de Biociências, Departamento de Genética e Biologia Evolutiva, \\ São Paulo, SP, Brazil. \\ ${ }^{2}$ Instituto Butantan, Laboratório de Genética, São Paulo, SP, Brazil. \\ ${ }^{3}$ Universidade Federal do Maranhão, Centro de Ciências Biológicas e da Saúde, \\ Departamento de Biologia, São Luis, MA, Brazil. \\ ${ }^{4}$ Universidade de São Paulo, Museu de Zoologia, São Paulo, SP, Brazil.
}

\begin{abstract}
Spiny rats of the genus Proechimys are morphologically diverse, widely distributed and have diploid numbers ranging from $2 n=14-16$ to $2 n=62$. In this paper we present cytogenetical data and brief comments on morphological and biogeographical issues related to spiny rats. In our sample of 42 spiny rats collected from 12 Brazilian Amazonian tropical rainforest and the Cerrado (Brazilian savanna) sites we detected nine karyological entities: four different karyomorphs with $2 n=30$, three with $2 n=28$, one with $2 n=15$ and one with $2 n=44$. Based on qualitative morphological characters these karyomorphs can be allocated to five species within the goeldii, guyannensis and longicaudatus species groups.
\end{abstract}

Key words: Proechimys, rodents, cytogenetics, karyomorph, morphology.

Received: August 20, 2004; Accepted: March 3, 2005.

\section{Introduction}

Spiny rats of the genus Proechimys are the most numerous terrestrial small mammals in Neotropical rainforests. Although spiny rats are very diverse and show a large geographic range, occurring from Honduras in Central America to Paraguay in South America (Emmons and Feer, 1997), Proechimys is still considered an ecologically and taxonomically poorly understood genus (Patton et al., 2000). Moojen (1948) revised the genus but new morphological, karyotypic and molecular studies have shown improvements in relation to this taxonomic work, indicating that the systematics of Proechimys is yet unresolved (Patton and Gardner, 1972; da Silva, 1998; Patton et al., 2000; Voss et al., 2001).

Although the extremely high character variability within and among populations, some progress has been made in defining species units and their probable geographic limits (Gardner and Emmons, 1984; Patton, 1987). Using several qualitative craniodental and bacular characters Patton (1987) defined nine groups of Proechimys spe-

Send correspondence to Maria José de J. Silva. Instituto Butantan, Laboratório de Genética, Avenida Vital Brasil 1500, 05503-900 São Paulo, SP, Brazil. E-mail: mariajo@butantan.gov.br. cies: (1) decumanus, (2) canicollis and (3) simonsi as monotypic groups; and (4) semispinosus, (5) longicaudatus, (6) goeldii, (7) guyannensis, (8) cuvieri and (9) trinitatus as polytipic groups. This grouping excluded the genus Trinomys, exclusively found in the Brazilian Atlantic rainforest, that was considered as a subgenus of Proechimys. In the most recent taxonomic list, Woods (1993) cited 32 species of Proechimys and also treated Trinomys as subgenus. More recently, however, divergencies in mitochondrial DNA sequences, morphological and cytogenetic characters as well as geographic distribution led Lara et al. (1996) and Lara and Patton (2000) to elevate Trinomys to the category of genus. The genus Proechimys inhabits Amazonian rainforest and Trinomys is exclusively found in Atlantic Forest. Patton et al. (2000) using cytogenetical, molecular, biogeographical and morphological approaches detected eight Proechimys species just along the Juruá River in Brazilian territory.

Cytogenetic studies have also been pointed to as an important tool for recognizing species in this taxon (Reig et al., 1980; Gardner and Emmons, 1984). Diploid numbers are found ranging from $2 \mathrm{n}=14-16$ to $2 \mathrm{n}=62$ (Reig and Useche, 1976; Barros, 1978; Reig et al., 1980; Aguilera and Corti, 1994; Aguilera et al., 1995; Weksler et al., 2001). 
In this paper we present new karyological data relating to 42 Proechimys specimens sampled from 12 localities in the Brazilian Amazonian tropical rainforest, transitional areas and the Cerrado (Brazilian savanna). Our results show nine different cytotypes, four karyomorphs with $2 \mathrm{n}=$ 30 , three with $2 \mathrm{n}=28$, one with $2 \mathrm{n}=15$ and one with $2 \mathrm{n}=$ 44. Based on their distribution and qualitative morphological data we allocated the nine Proechimys cytotypes to five different goeldii, guyannensis and longicaudatus species groups. These results provide cytogenetical data and help with the cytotaxonomy of Proechimys species and the identification of its probable geographic limits.

\section{Material and Methods}

We analyzed 42 specimens of the genus Proechimys from 12 localities in Brazilian Amazonian tropical rainforest, transitional areas and Cerrado (Table 1 and Figure 1). Skulls and skins were deposited in the Museu de Zoologia da Universidade de São Paulo (MZUSP) and in the Museu Nacional, Rio de Janeiro (see Appendix).

Bone marrow and spleen mitotic metaphases were obtained after in vivo colchicine treatment. Fibroblast cultures derived from tail, ear and embryos biopsies were established using Dulbecco's Modified Eagle Medium supplemented with $20 \%$ fetal bovine serum and standard methods. We performed GTG- and CBG-banding and silver nucleolar organizer region (Ag-NOR) staining using routine cytogenetic techniques. Triple $\mathrm{CMA}_{3} / \mathrm{DA} / \mathrm{DAPI}$ staining was performed according to Schweizer (1980), with modifications. For some specimens, fluorescence in situ hybridization (FISH) was conducted following the telomeric probe protocol (All Human Telomeres P5097-DG5-Oncor, digoxigenin labeled).

Qualitative craniodental and bacular characters of adult specimens were examined in order to allocate the specimens into one of the nine species groups defined by Patton (1987) and to species level, when possible. The individuals were classified as adults based on the tooth wear pattern (ages 8 to 10) following Patton and Rogers (1983). The qualitative characters analyzed were: (i) shape and structure of the incisive foramen, (ii) angle and depth of mesopterygoid fossa, (iii) degree of development of the temporal ridges across the parietals, (iv) degree of development of a bony groove in the floor of the infraorbital foramen, and (v) the counterfold pattern of the upper and lower cheekteeth. Overall sizes of the baculum of adult Proechimys specimens were measured, comparing the proportions of length and width obtained with the ones provided by Patton (1987) for the different species groups. The bacular shape and the presence of apical wings or extensions were also analyzed and included in the comparisons.

The species nomenclature follows Woods (1993) and Weksler et al. (2001). The only specimen not morphologically examined by us was one from the city of Manaus in the Brazilian state of Amazonas (AM), which was previously identified by Jay R. Malcolm.

\section{Results}

We observed nine different Proechimys cytotypes in the 42 specimens collected (Table 1; Figure 1). Table 1 was organized from the lowest to the highest diploid numbers and karyotypes with $2 \mathrm{n}=28$ and $2 \mathrm{n}=30$ were classified from $\mathrm{A}$ to $\mathrm{G}$ according to diploid and fundamental numbers and chromosome morphologies.

We separated the karyomorphs as follows: Proechimys gr. goeldii $(2 \mathrm{n}=15, \mathrm{FN}=16)$ from the town of Juruena in Mato Grosso (MT) state; Proechimys longicaudatus karyomorph A $(2 \mathrm{n}=28, \mathrm{FN}=48)$ from Usina Hidrelétrica Samuel (Samuel Hydroelectric station) in Rondônia (RO) state and from the towns of Aripuanã and Juruena (MT); Proechimys longicaudatus karyomorph B $(2 \mathrm{n}=28, \mathrm{FN}=50)$ from the town of Apiacás (MT); Proechimys longicaudatus karyomorph C $(2 \mathrm{n}=28$, $\mathrm{FN}=50$ ) from Parque Nacional das Emas (Emas National Park) in Goiás (GO) state; Proechimys roberti karyomorph $\mathrm{D}(2 \mathrm{n}=30, \mathrm{FN}=56)$ from Estação Ecológica de Uruçuí-Una (Uruçuí-Una Ecological Station) in Piauí state (PI) and the towns of Peixe and Paranã in Tocantins state (TO); Proechimys roberti karyomorph $\mathrm{E}(2 \mathrm{n}=30, \mathrm{FN}=56)$ from the towns of Cláudia and Gaúcha do Norte (MT); Proechimys roberti karyomorph $\mathrm{F}(2 \mathrm{n}=30, \mathrm{FN}=56)$ from the town of Vila Rica (MT); Proechimys gr. longicaudatus karyomorph G $(2 \mathrm{n}=30, \mathrm{FN}=52)$ from Usina Hidrelétrica Samuel; and Proechimys sp. $(2 \mathrm{n}=44, \mathrm{FN}=52)$ from the city of Manaus in Amazonas state (AM).

\section{Karyotype descriptions}

1) Proechimys gr. goeldii $(2 \mathrm{n}=15, \mathrm{FN}=16)$ from Juruena (MT)

This karyotype includes one pair of large submetacentrics (pair 1), four pairs of medium to small acrocentrics (pairs 4-7), one large submetacentric (chromosome 2/3) and two medium acrocentrics (chromosomes 2 and 3 ) which are homologous to the short and long arms respectively of the odd submetacentric $2 / 3$. The X-chromosome is a medium-sized acrocentric (Figure 2a). Interstitial AgNORs were detected in the long arm of chromosome pair 7 (Figure 2b).

The C-banding pattern shows conspicuous heterochromatic pericentromeric blocks in all chromosomes, except for the rearranged chromosome $2 / 3$ that has a slight pericentromeric band. Chromosome pair 1 presented an interstitial band in the short arm (Figure 2c). Triple $\mathrm{CMA}_{3} /$ DA/DAPI staining revealed R-banding pattern (Figure 2d). FISH with telomeric probes showed signals at both telomeres of all chromosomes. Interstitial signals were not detected (Figure 2e). 
Table 1 - Species, karyomorph (K), diploid number (2n), fundamental number $(\mathrm{FN})$, sex (female = F; male $=\mathrm{M})$, locality and number of the localities shown on the map (Figure 1).

\begin{tabular}{|c|c|c|c|c|c|c|}
\hline Proechimys species & $\mathrm{K}$ & $2 \mathrm{n}$ & FN & Sex & Locality & $\begin{array}{l}\text { Map } \\
\text { reference }\end{array}$ \\
\hline Proechimys gr. goeldii & - & 15 & 16 & $1 \mathrm{~F}$ & Juruena $\left(10^{\circ} 19^{\prime} \mathrm{S}, 58^{\circ} 29^{\prime} \mathrm{W}\right)$, Mato Grosso state & 1 \\
\hline Proechimys longicaudatus* & A & 28 & 48 & $3 \mathrm{M}, 3 \mathrm{~F}$ & $\begin{array}{l}\text { Usina Hidrelétrica Samuel, Jamari River }\left(08^{\circ} 45^{\prime} \mathrm{S} \text {, }\right. \\
63^{\circ} 26^{\prime} \text { W), Rondônia state }\end{array}$ & 11 \\
\hline Proechimys longicaudatus & A & 28 & 48 & $4 \mathrm{M}, 2 \mathrm{~F}$ & Aripuanã $\left(10^{\circ} 10^{\prime} \mathrm{S}, 59^{\circ} 27^{\prime} \mathrm{W}\right)$, Mato Grosso state & 2 \\
\hline Proechimys longicaudatus & A & 28 & 48 & $3 \mathrm{~F}$ & Juruena $\left(10^{\circ} 19^{\prime} \mathrm{S}, 58^{\circ} 29^{\prime} \mathrm{W}\right)$, Mato Grosso state & 1 \\
\hline Proechimys longicaudatus & B & 28 & 50 & $2 \mathrm{M}, 5 \mathrm{~F}$ & Apiacás $\left(09^{\circ} 34^{\prime} \mathrm{S}, 57^{\circ} 23^{\prime} \mathrm{W}\right)$, Mato Grosso state & 3 \\
\hline Proechimys longicaudatus** & $\mathrm{C}$ & 28 & 50 & $2 \mathrm{M}$ & $\begin{array}{l}\text { Parque Nacional das Emas }\left(18^{\circ} 15^{\prime} \mathrm{S}, 52^{\circ} 53^{\prime} \mathrm{W}\right) \text {, } \\
\text { Goiás state }\end{array}$ & 7 \\
\hline Proechimys roberti & $\mathrm{D}$ & 30 & 56 & $2 \mathrm{M}, 1 \mathrm{~F}$ & $\begin{array}{l}\text { Estação Ecológica de Uruçuí-Una ( } 08^{\circ} 52^{\prime} \text { S, } \\
44^{\circ} 58^{\prime} \text { W), Piauí state }\end{array}$ & 10 \\
\hline Proechimys roberti & $\mathrm{D}$ & 30 & 56 & $1 \mathrm{M}$ & 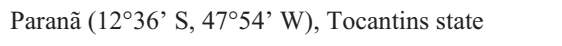 & 8 \\
\hline Proechimys roberti & $\mathrm{D}$ & 30 & 56 & $2 \mathrm{~F}$ & Peixe $\left(12^{\circ} 15^{\prime}\right.$ S, $\left.48^{\circ} 24^{\prime} \mathrm{W}\right)$, Tocantins state & 9 \\
\hline Proechimys roberti & $\mathrm{E}$ & 30 & 56 & $2 \mathrm{M}, 3 \mathrm{~F}$ & Cláudia $\left(11^{\circ} 35^{\prime} \mathrm{S}, 55^{\circ} 08^{\prime} \mathrm{W}\right)$, Mato Grosso state & 4 \\
\hline Proechimys roberti & $\mathrm{E}$ & 30 & 56 & $1 \mathrm{M}, 1 \mathrm{~F}$ & $\begin{array}{l}\text { Gaúcha do Norte }\left(13^{\circ} 02^{\prime} \mathrm{S}, 53^{\circ} 12^{\prime} \mathrm{W}\right) \text {, Mato } \\
\text { Grosso state }\end{array}$ & 5 \\
\hline Proechimys roberti & $\mathrm{F}$ & 30 & 56 & $2 \mathrm{M}$ & Vila Rica $\left(09^{\circ} 54^{\prime} \mathrm{S}, 51^{\circ} 12^{\prime} \mathrm{W}\right)$, Mato Grosso state & 6 \\
\hline $\begin{array}{l}\text { Proechimys gr. } \\
\text { longicaudatus* }\end{array}$ & G & 30 & 52 & $1 \mathrm{~F}$ & $\begin{array}{l}\text { Usina Hidrelétrica Samuel, Jamari River }\left(08^{\circ} 45^{\prime}\right. \\
\text { S, } 63^{\circ} 26^{\prime} \text { W), Rondônia state }\end{array}$ & 11 \\
\hline Proechimys sp.* & - & 44 & 52 & $1 \mathrm{M}$ & $\begin{array}{l}\text { Acampamento Cabo Frio, Manaus }\left(03^{\circ} 07^{\prime} \mathrm{S},\right. \\
\left.60^{\circ} 02^{\prime} \mathrm{W}\right) \text {, Amazonas state }\end{array}$ & 12 \\
\hline Total & & & & $20 \mathrm{M}, 22 \mathrm{~F}$ & & \\
\hline
\end{tabular}

*Karyotype data extracted from Leal-Mesquita (1991).

**Karyotype data extracted from Rodrigues et al. (2002).

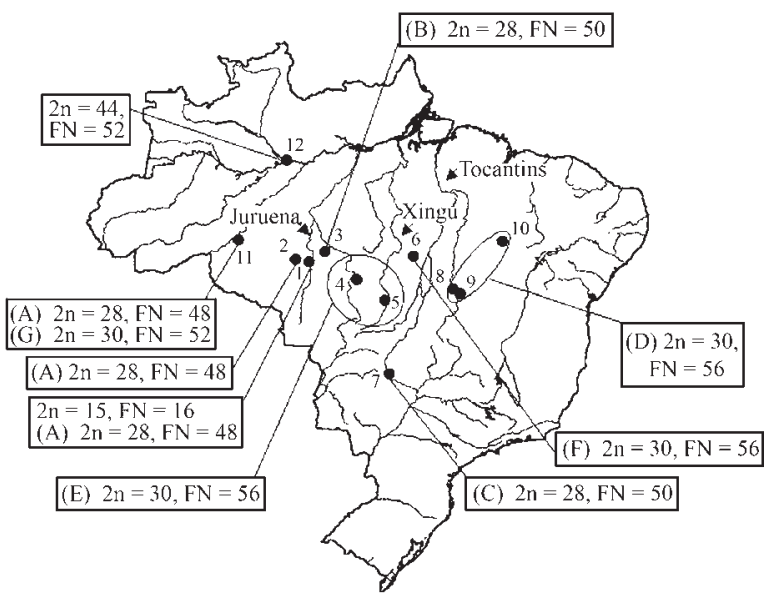

Figure 1 - Collection localities in Brazil and diploid and fundamental numbers of Proechimys specimens (numbers indicate locality records): 1, 2, 3, 6, 11 and 12: located in the Amazonian rainforest biome; 4-5: located in transitional areas between Amazonian rainforest and Cerrado biomes; 7-10: located in the Cerrado biome. (1) Juruena; (2) Aripuanã; (3) Apiacás; (4) Cláudia; (5) Gaúcha do Norte; (6) Vila Rica, Mato Grosso state; (7) Parque Nacional das Emas (PNE), Goiás state; (8) Paranã and (9) Peixe, Tocantins state; (10) Estação Ecológica de Uruçuí-Una, Piauí state; (11) Usina Hidrelétrica Samuel, Jamari River, Rondônia state; and (12) Manaus, Amazonas state. Capital letters (A-G) represent different karyomorphs of $2 \mathrm{n}=28$ and $2 \mathrm{n}=30$. The rivers (Xingu, Tocantins and Juruena) are also shown.
2) Karyomorph A $(2 \mathrm{n}=28, \mathrm{FN}=48)$ : Proechimys longicaudatus from Usina Hidrelétrica Samuel (RO), and from Aripuanã and Juruena (MT)

The specimen identified as $P$. longicaudatus in LealMesquita (1991) presented a karyotype composed of 11 pairs of metacentrics and submetacentrics (pairs 1, 2, 4-10, 12 and 13) decreasing from large to small; one pair of large acrocentrics (pair 3) and one pair of small subtelocentrics (pair 11). The X-chromosome is a medium submetacentric and the $\mathrm{Y}$ a small acrocentric (Figure 3a). Chromosome pair 8 has an interstitial secondary constriction in the long arm, which is equivalent to the NOR (Figure $3 b$ ).

C-banding pattern shows conspicuous pericentromeric blocks of heterochromatin in all chromosomes, except for the $\mathrm{Y}$ that is entirely euchromatic (Figure 3c). The GTG-bands also allowed the recognition of all chromosome homologues and $\mathrm{X}$ and $\mathrm{Y}$ as well (Figure 3d).

The karyotype of the Mato Grosso specimens is identical to that of the Rondônia specimen, except for the fact that the $\mathrm{Y}$ chromosome is a small submetacentric. C-banding revealed small amounts of constitutive heterochromatin restricted to pericentromeric blocks of both chromosome pair 1 and the $\mathrm{Y}$ chromosome (Figure 3e) and exhibited a different pattern when compared to the one described just above. 
3) Karyomorph B $(2 \mathrm{n}=28, \mathrm{FN}=50)$ : Proechimys longicaudatus from Apiacás (MT)

This karyotype has 12 pairs of large to small metacentrics and submetacentrics decreasing in size (pairs 1, 2, 4-13) and one large acrocentric (pair 3) (Figure 4a). Chromosome pair 8 presents a large interstitial secondary constriction in the long arm, which is Ag-NOR stained. The $\mathrm{X}$-chromosome is a medium-sized submetacentric and the Y a small acrocentric (Figure 4a).
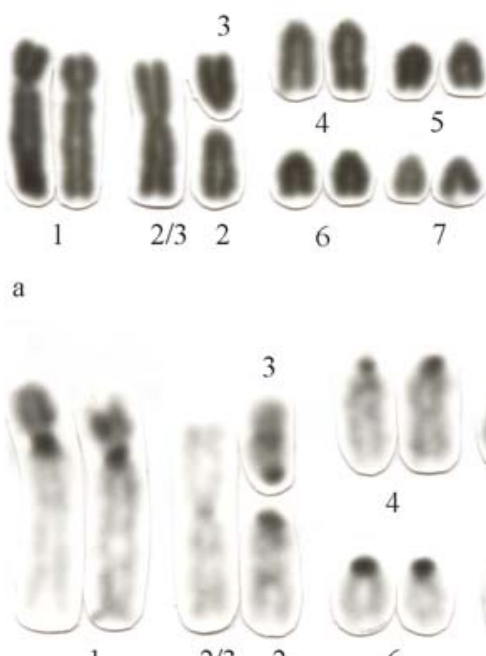

1

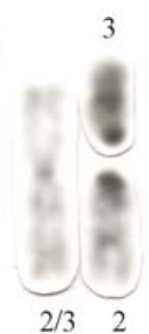

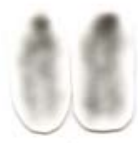

4

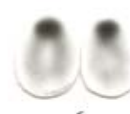

6

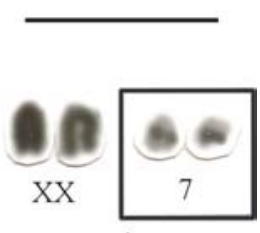

b c
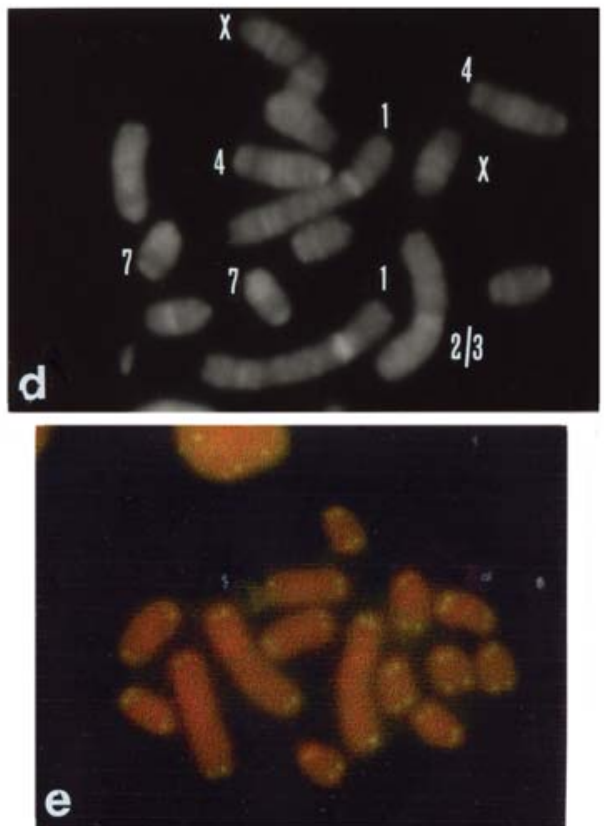

Figure 2 - a) Conventionally stained karyotype of Proechimys gr. goeldii with $2 \mathrm{n}=15, \mathrm{FN}=15$ from Juruena (MT). The odd diploid number is due to a Robertsonian rearrangement involving chromosomes 2 and 3 ; b) Ag-NORs in the interstitial region of the long arm of chromosome pair 7; c) C-banding pattern; d) triple staining $\mathrm{CMA}_{3} / \mathrm{DA} / \mathrm{DAPI}$ revealed R-banding pattern; e) FISH (fluorescence in situ hybridization) with telomeric probes showing exclusively telomeric signals. Bar $=10 \mu \mathrm{m}$.
The C-banding pattern exhibits tenuous telomeric, pericentromeric and interstitial constitutive heterochromatin, except for pairs 1,2, 4 and 9 that show evident pericentromeric blocks (Figure 4b).
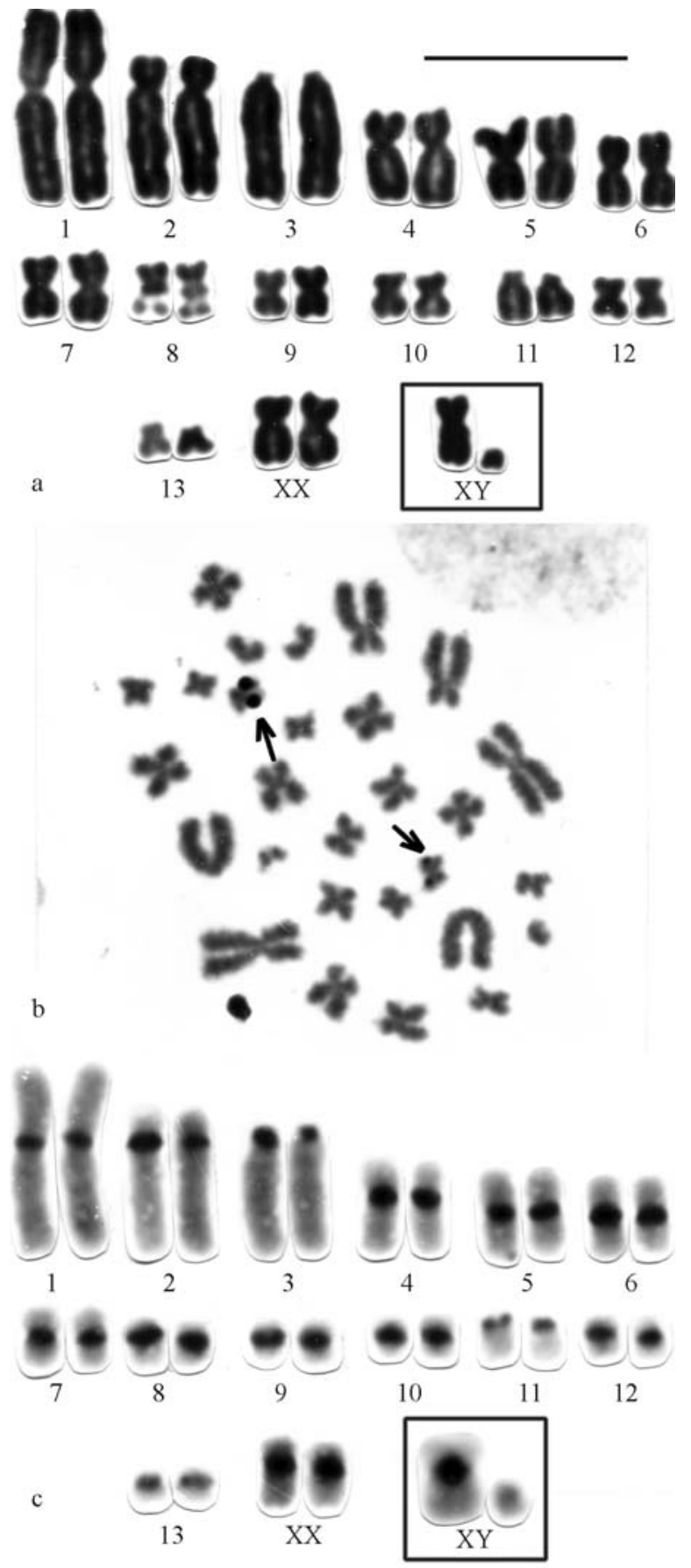

Figure 3(a-c) - Karyomorph A with $2 \mathrm{n}=28, \mathrm{FN}=48$ : a) to d) Proechimys longicaudatus from Usina Hidrelétrica Samuel (RO). a) Karyotype conventionally stained. Note secondary constriction in chromosome pair 8 ; b) Heteromorphic Ag-NORs in the distal region of the long arm of chromosome pair 8 (arrows); c) C-banding pattern. Bar $=10 \mu \mathrm{m}$. 


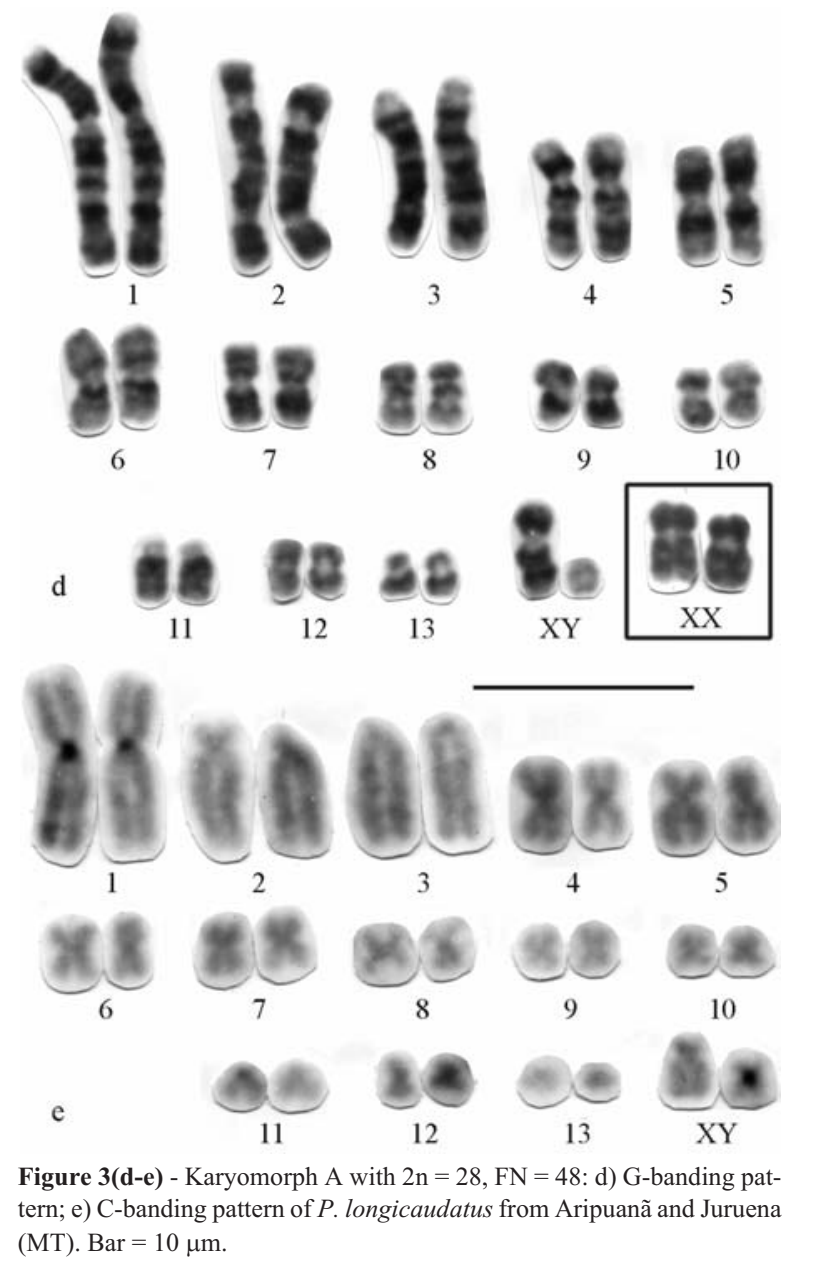

4) Karyomorph $\mathrm{C}(2 \mathrm{n}=28, \mathrm{FN}=50)$ : Proechimys longicaudatus from Parque Nacional das Emas (GO)

This karyotype includes 12 pairs of metacentrics and submetacentrics decreasing from large to small (pairs 1-10, 12-13) and one pair of small subtelocentrics (pair 11). The $\mathrm{X}$-chromosome is a medium size acrocentric and the $\mathrm{Y}$ a small acrocentric (Figure 5a). Chromosome pair 8 presents an interstitial secondary constriction in the long arm, equivalent to the NOR.

The C-banding pattern revealed pericentromeric blocks of heterochromatin in all chromosomes, except for pair 5. Chromosome pairs 2, 3, 6, 8, 9, 10, 12 and 13 have conspicuous heterochromatin blocks, in contrast to pairs 1 , 7 and 11 that show weak C-bands. Chromosome pair 4 showed heteromorphism of C-bands in the pericentromeric region. The $\mathrm{X}$ chromosome is clearly recognizable after C-banding because it has a strong interstitial band in the long arm (Figure 5b).

5) Karyomorph D $(2 \mathrm{n}=30, \mathrm{FN}=56)$ : Proechimys roberti from Estação Ecológica de Uruçuí-Una (PI) and Paranã and Peixe (TO)

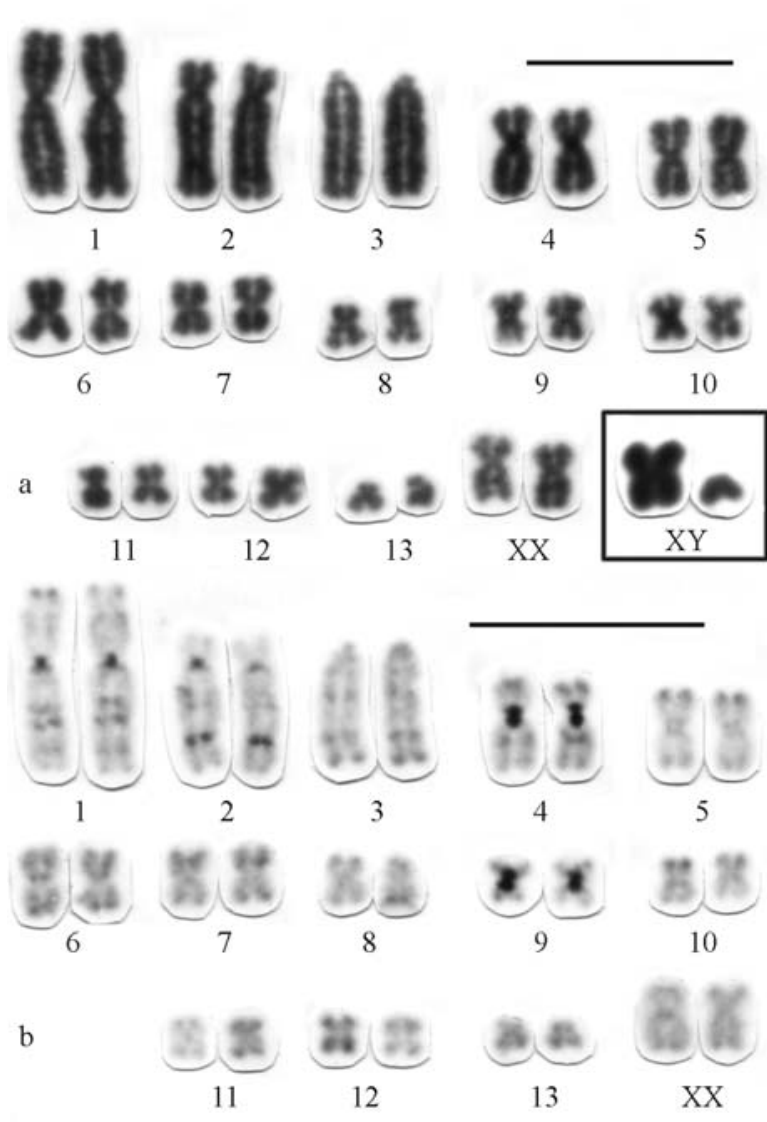

Figure 4 - Karyomorph B with $2 \mathrm{n}=28, \mathrm{FN}=50$ of $P$. longicaudatus from Apiacás (MT): a) Karyotype conventionally stained; b) C-banding pattern. Bar $=10 \mu \mathrm{m}$.

This karyotype includes 12 pairs of metacentric and submetacentrics that range from large to small (pairs 1-12), pair 13 is a small subtelocentric and pair 14 is a minute metacentric. The X-chromosome is a medium-sized submetacentric (Figure 6a) and the $\mathrm{Y}$ a small acrocentric (not shown). Chromosome pair 9 presents an interstitial secondary constriction in the long arm, which is equivalent to the NOR.

The C-banding pattern revealed few heterochromatic regions, with evident telomeric blocks in the short arms of pairs $3,6,7,9$ and 11 ; in both telomeric regions of pair 10; in the telomeric region of the long arm of pair 13 and a weak pericentromeric band in the pair 9 . The $\mathrm{X}$ chromosomes do not exhibit heterochromatic blocks (Figure 6b).

6) Karyomorph E $(2 \mathrm{n}=30, \mathrm{FN}=56)$ : Proechimys roberti from Cláudia and Gaúcha do Norte (MT)

This karyotype has 12 pairs of metacentric and submetacentrics that range from large to small (pairs 1-12) and two small subtelocentrics (pairs 13 and 14). The Xchromosome is a medium-sized submetacentric and the $\mathrm{Y}$ is a small acrocentric (Figure 7). Chromosome pair 9 pres- 


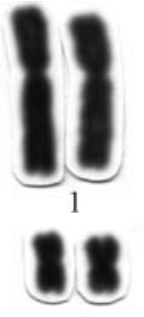

6

a

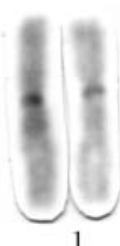

1

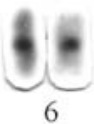

b

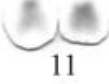

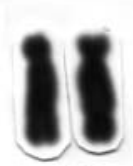

3

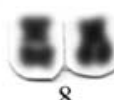

8
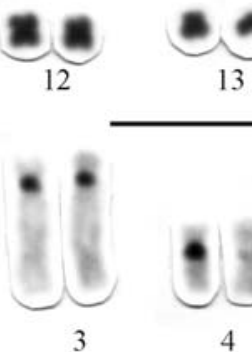

4
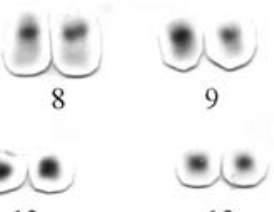

13

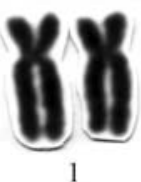

1

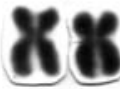

6

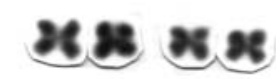

11

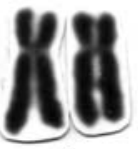

2

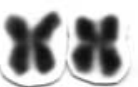

7

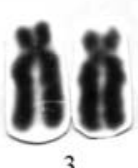

3

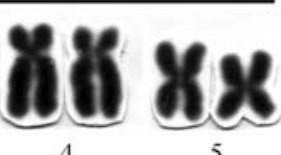

4

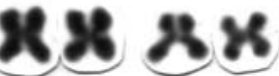

8

9

$\boldsymbol{x} \boldsymbol{x}$

10

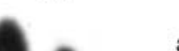

XY

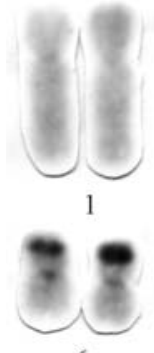

6

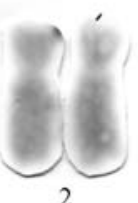

2

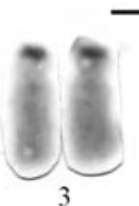

3
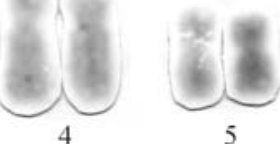

5
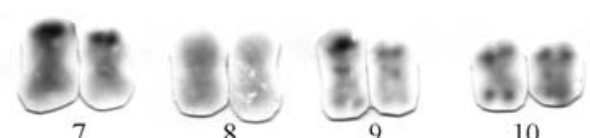

10

b
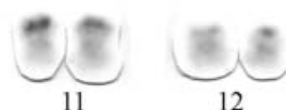

12

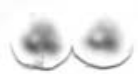

13

4

$\mathrm{XX}$

Figure 6 - Karyomorph D with $2 \mathrm{n}=30, \mathrm{FN}=56$ of $P$. roberti from Uruçuí-Una (PI): a) Karyotype conventionally stained; b) C-banding pattern. Bar $=10 \mu \mathrm{m}$.

Parque Nacional das Emas (GO): a) Karyotype conventionally stained; b) C-banding pattern. Bar $=10 \mu \mathrm{m}$.

ents an interstitial secondary constriction in the long arm, which is equivalent to the Ag-NORs.

7) Karyomorph F $(2 \mathrm{n}=30, \mathrm{FN}=56)$ : Proechimys roberti from Vila Rica (MT)

This karyotype is composed of 13 metacentric/submetacentrics which decrease in size (pairs 1-13) and pair 14 is a small subtelocentric. The $\mathrm{X}$-chromosome is a mediumsized subtelocentric and the $\mathrm{Y}$ a small submetacentric (Figure 8). Chromosome pair 9 shows an interstitial secondary constriction in the long arm, which is Ag-NOR stained.

8) Karyomorph G $(2 \mathrm{n}=30, \mathrm{FN}=52)$ : Proechimys gr. longicaudatus from Usina Hidrelétrica de Samuel (RO)

This karyotype includes 12 pairs of metacentric and submetacentrics from large to small (pairs 1, 2, 4-11, 13 and 14), two acrocentric pairs being one large (pair 3) and one small (pair 12). The $\mathrm{X}$-chromosome is a medium-sized submetacentric (Figure 9). Chromosome pair 9 has a large interstitial secondary constriction in the long arm, equivalent to the Ag-NORs.

The C-banding pattern shows conspicuous pericentromeric blocks of heterochromatin in all chromosomes (not shown). GTG-bands allowed the recognition of all the homologues and $\mathrm{X}$ and $\mathrm{Y}$ chromosomes. Figure 10 shows comparison of G-banding pattern between specimens with $2 n=28$ and $2 n=30$ from Usina Hidrelétrica Samuel.

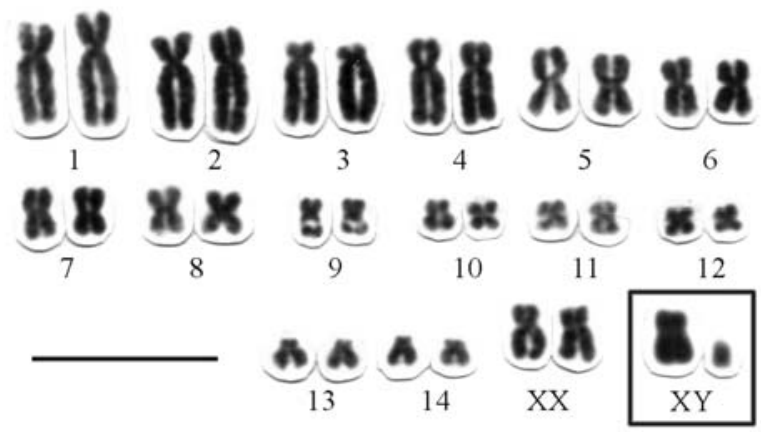

Figure 7 - Karyomorph E conventionally stained with $2 \mathrm{n}=30, \mathrm{FN}=56$ of P. roberti from Cláudia and Gaúcha do Norte (MT). Bar $=10 \mu \mathrm{m}$.

9) Proechimys sp. $(2 \mathrm{n}=44, \mathrm{FN}=52)$ from Manaus (AM)

This karyotype comprises one pair of large (pair 1) and two medium-sized submetacentrics (pairs 4 e 5); one pair of medium (pair 11) and one small metacentric (pair 21 ) and two pairs of large (pairs 2 and 3 ) and 14 medium to small acrocentrics (pairs 6-10 and 12-20). The X-chromosome is a medium-sized subtelocentric and the $\mathrm{Y}$ a small acrocentric (Figure 11). Chromosome pair 5 presents a 

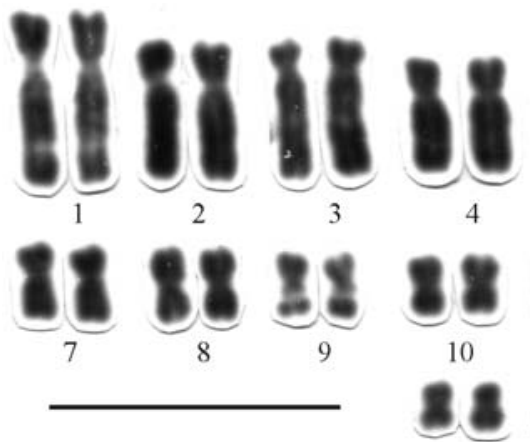

13
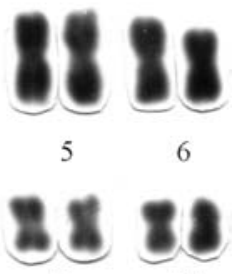

11

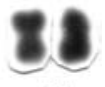

12

$\mathrm{XY}$

Figure 8 - Karyomorph F conventionally stained with $2 \mathrm{n}=30, \mathrm{FN}=56$ of P. roberti from Vila Rica (MT). Bar $=10 \mu \mathrm{m}$.

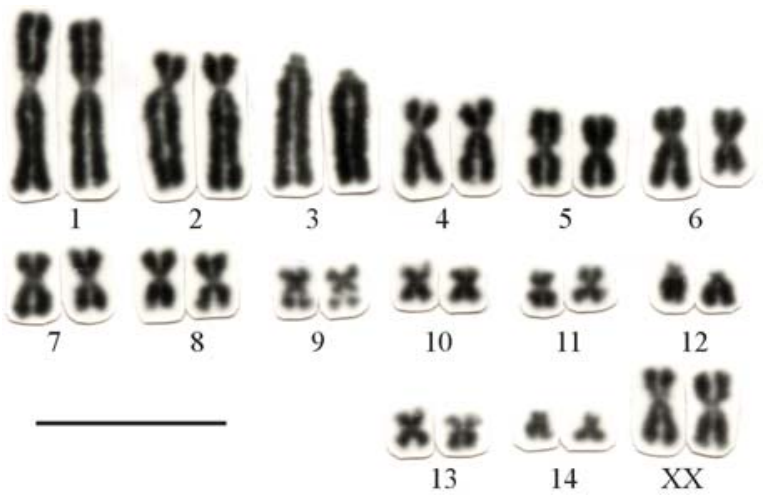

Figure 9 - Karyomorph G conventionally stained with $2 \mathrm{n}=30, \mathrm{FN}=52$ of $P$. gr. longicaudatus from Usina Hidrelétrica Samuel (RO). Bar $=10 \mu \mathrm{m}$.

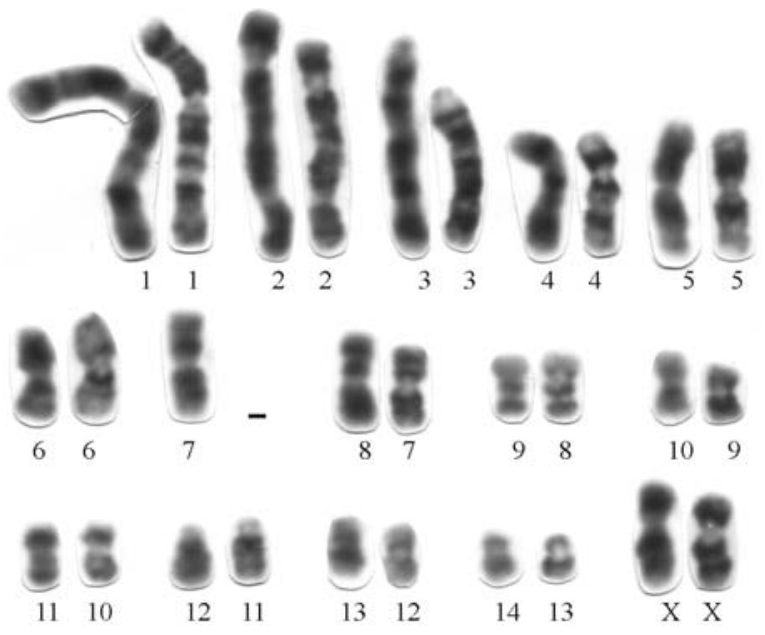

Figure 10 - Comparison between $2 \mathrm{n}=30$ (left) and $2 \mathrm{n}=28$ (right) karyomorphs from Usina Hidrelétrica Samuel (RO).

large interstitial secondary constriction in the long arm, which is Ag-NOR stained.

G-band allowed the recognition of all homologous. The C-banding patterns show conspicuous pericentromeric

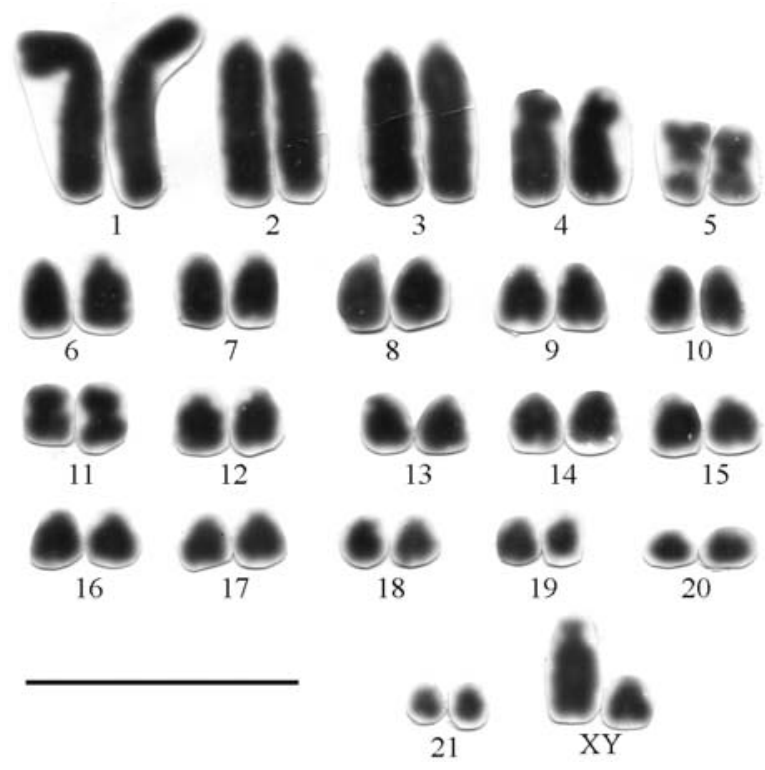

Figure 11 - Karyotype conventionally stained with $2 \mathrm{n}=44, \mathrm{FN}=52$ of Proechimys sp. from Manaus (AM). Bar $=10 \mu \mathrm{m}$.

blocks of heterochromatin in all chromosomes and Y, except for pair 1 . The $\mathrm{X}$-chromosome presents a slightly stained C-band in the short arm and in the proximal region of long arm (not shown).

\section{Cranial and bacular qualitative characters}

1) Proechimys gr. goeldii $(2 \mathrm{n}=15, \mathrm{FN}=16)$ from Juruena (MT)

The analysis of the skull of this female specimen (MZUSP 31924) provided the qualitative cranial characters to include it in the goeldii species group, the characters being: an incisive foramen moderately lyre-shaped with margins slightly tapering in the posterior portion, a short premaxillary portion of the septum, less than half of the foramen length, with the vomer not exposed ventrally; posterolateral margins slightly flanged and a moderate groove onto the anterior palate, with no ridges extending onto it. Mesopterygoid fossa extending to the anterior one-half of the third molar (moderate degree of penetration) and presenting a moderate angle; presence of a weak temporal ridge onto the parietals; no groove present in the ventral canal of the infraorbital foramen; and a counterfold pattern of the cheekteeth with 3-3-3-1 folds respectively.

2) Karyomorph A $(2 \mathrm{n}=28, \mathrm{FN}=48)$ : Proechimys longicaudatus from Usina Hidrelétrica Samuel (RO), and from Aripuanã and Juruena (MT)

These specimens presented an incisive foramen lyreshaped, not strongly constricted posteriorly, with posterolateral margins flanged but not expanded, the maxillary terminus deeply grooved onto the anterior palate, a long premaxillary portion of the septum representing more than one half of the foramen length, the vomer ven- 
trally exposed, and a well developed and strongly keeled maxillary portion which extends onto the anterior palate forming a moderately developed median ridge. Mesopterygoid fossa extending to the posterior one-half of the third molar (shallow) and presenting a broad angle; temporal ridge moderately developed; no groove present in the ventral canal of the infraorbital foramen; and a counterfold pattern of the cheekteeth with 3-3-3-3 folds respectively. These craniodental qualitative characters together with the presence of an elongate (around $12.0 \mathrm{~mm}$ ) and broad (around $4.0 \mathrm{~mm}$ ) baculum, with a arched shaft, moderately developed apical wings, concave margins similar in width on both proximal and distal portions, and the proximal end presenting a slightly developed median identation with a median notch moderate in depth, clearly point to members of the longicaudatus species group.

3) Karyomorph B $(2 \mathrm{n}=28, \mathrm{FN}=50)$ : Proechimys longicaudatus from Apiacás (MT) and 4) Karyomorph C $(2 \mathrm{n}=28, \mathrm{FN}=50)$ : Proechimys longicaudatus from Parque Nacional das Emas (GO)

Although all the specimens analyzed from these two localities were not in adult age classes (young and sub-adult age classes), the shape of the baculum analyzed (MZUSP 31935 from Apiacás, MT) was very similar to those found in the specimens from Usina Hidrelétrica Samuel. Also, the shape and structure of the incisive foramen were very similar, indicating that these specimens belong to the longicaudatus species group.

5) Karyomorph D $(2 \mathrm{n}=30, \mathrm{FN}=56)$ : Proechimys roberti from Estação Ecológica de Uruçuí-Una (PI) and Paranã and Peixe (TO); 6) Karyomorph E (2n = 30, $\mathrm{FN}=56$ ): Proechimys roberti from Cláudia and Gaúcha do Norte (MT) and 7) Karyomorph F $(2 \mathrm{n}=30, \mathrm{FN}=56)$ : Proechimys roberti from Vila Rica (MT)

All specimens analyzed showed an incisive foramen slightly lyre-shaped to oval, with posterolateral margins not or slightly flanged, a flat anterior palate, with no or moderate grooves and ridges, a premaxillary portion of the septum short, a maxillary portion usually not in contact with the premaxillary one, and the vomer not exposed ventrally. Mesopterygoid fossa extending to posterior one-half of the third molar (shallow) and presenting a broad angle; weak or no temporal ridge development; no groove present in the ventral canal of the infraorbital foramen; and a counterfold pattern of the cheekteeth with 3-3-3-3 folds respectively. The baculum of the specimens from Estação Ecológica de Uruçuí-Una (PI) and Peixe (TO) were very similar in size and shape, being long (around $8.0 \mathrm{~mm}$ ) and narrow (around $2.0 \mathrm{~mm}$ ), with moderate dorsoventral curvature, the shaft slightly concave with moderately tapered lateral identations, absence of apical wings, and a proximal end rounded with a small median notch. These qualitative characters place these specimens as members of the guyannensis species group.
8) Karyomorph G $(2 \mathrm{n}=30, \mathrm{FN}=52)$ : Proechimys gr. longicaudatus from Usina Hidrelétrica de Samuel (RO)

The only female specimen examined (MZUSP 27396) showed craniodental qualitative characters similar to those found in the longicaudatus species group.

\section{Discussion}

In this report we present nine different karyotypes detected in 42 specimens of the genus Proechimys collected from 12 Brazilian localities (Figure 1), revealing a remarkable variability in diploid number, chromosome morphologies and banding patterns.

The karyotype with $2 n=15$ of a specimen from Juruena (MT) presents an odd diploid number due to a rearrangement of centric fusion involving chromosomes 2 and 3 after loss of heterochromatic and telomeric sequences detected using C-banding and FISH with telomeric probes. Interstitial telomeric signals (ITS) after FISH were not detected. A similar karyotype was described by Barros (1978) in a specimen captured in the Brazilian state of Pará at the Jacareacanga-Flexal section of the trans-Amazon highway. Since we had only one female, sex chromosomes were identified based on our fluorochrome staining and on previous report by Barros (1978). Undoubtedly this karyotype plus the qualitative morphological data represent one taxonomic entity belonging to the goeldii species group. Species from this group show low diploid numbers: Proechimys goeldii $(2 \mathrm{n}=24, \mathrm{FN}=44), P$. quadruplicatus $(2 \mathrm{n}=26-28, \mathrm{FN}=42-44)$ and $P$. steerei $(2 \mathrm{n}=24$, $\mathrm{FN}=40-42)$ (Patton et al., 2000). The other nine nominal taxa referred by Patton (1987) as part of the goeldii species group presented no karyotypic data. The type localities and range of distribution of these nominal taxa are not geographically close to Juruena (MT), which is located in the extreme southern range of the goeldii species group distribution. It was not possible to associate any of these names to the specimen analyzed here, because to do it would have required a comparison with the type specimens of the different nominal taxa included in the goeldii species group in order to define its taxonomic status.

Regarding karyotypes with $2 \mathrm{n}=28$ presented here, cytotype A was found in three localities: Aripuanã, Juruena (MT) and Usina Hidrelétrica Samuel (RO); karyomorph B in Apiacás (MT) only; and karyomorph $\mathrm{C}$ in Parque Nacional das Emas (GO). Strong similarity between these karyomorphs (A, B and C) in conventional staining was observed and also they shared the presence of interstitial secondary constriction and Ag-NOR in the long arm of chromosome pair 8 . The difference between karyomorph $\mathrm{B}$ and karyomorphs $\mathrm{A}$ and $\mathrm{C}$ is due to chromosome pair 11 which is a small submetacentric in the former and subtelocentric in A and C. Additionally, chromosome pair 3 is acrocentric in A and B and submetacentric in C. Basically, these differences are due to pericentric inversion mechanisms of chromosome pair 3 and 11. However, C-banding 
patterns revealed more differences than observed in conventional staining: samples from Juruena and Aripuanã (MT) with karyomorph A (Figure 1) shared the same pattern (Figure 3c) but specimens with the same karyomorph from Usina Hidrelétrica de Samuel (RO) exhibited a peculiar pattern (Figure 3e).

Karyomorphs B (Figure 4b) and C (Figure 5b) can also be distinguished as two different karyotypical entities in respect of geographical distribution (especially karyomorph C, which is $1115 \mathrm{~km}$ from Aripuanã, Juruena and Apiacás) and the addition/deletion of constitutive heterochromatin. In rodents the addition/deletion of constitutive heterochromatin is theoretically more likely than pericentric or paracentric inversions because changes in heterochromatin are common and lead to neutral or adaptive changes while pericentric inversion is considered to be a potential post-mating isolating mechanisms (King, 1993). It is clear that these samples have been accumulating small differences concerning pericentric inversions and addition/ deletion of constitutive heterochromatin. Moreover karyomorphs A from Juruena and Aripuanã are separated from samples with karyomorph B from Apiacás by the Juruena River.

Specimens with $2 \mathrm{n}=28, \mathrm{FN}=48$ (karyomorph A) were detected in three different localities (1,2 and 11 in Figure 1) and, although they present differences in amounts of constitutive heterochromatin, they may belong to the same taxonomic entity based on the analysis of the craniodental qualitative characters. The specimens from Usina Hidrelétrica Samuel (RO), were reported as $P$. longicaudatus (Leal-Mesquita, 1991) but this karyotype is almost identical to $P$. cuvieri from Amazonas state with $2 \mathrm{n}=28, \mathrm{FN}=46-48$ (Patton et al., 2000). Although species from the cuvieri group resembles species of the longicaudatus group in several craniodental qualitative characters, the shape and structure of the baculum are quite different (Patton, 1987). The baculum of the specimens analyzed here were typical of the longicaudatus species group, elongate and broad (sensu Patton, 1987).

Karyomorph B is also similar to $P$. cuvieri from French Guiana although there is no banding pattern available (Reig et al., 1979). However, these specimens, as well as the specimens cited above, present a baculum typical of the longicaudatus species group.

Karyomorph $\mathrm{C}$, also reported as $P$. longicaudatus (Rodrigues et al., 2002), resembles $P$. brevicauda from Juruá River, Acre state, Brazil (Patton et al., 2000) indicating, together with craniodental features, the inclusion of these specimens within the longicaudatus species group. We consider the samples with $2 \mathrm{n}=28, \mathrm{FN}=50$ from Apiacás (MT) and Parque Nacional das Emas (GO) as two different karyotypical entities because of their genetic differences which include pericentric inversions and addition/deletion of constitutive heterochromatin plus their geographic distribution. In relation to their qualitative mor- phology, however, these specimens could not be segregated.

Patton (1987) considered two species within the longicaudatus group: P. longicaudatus occurring from eastern Bolivia east through adjacent Brazil into northern Paraguay, and P. brevicauda in northern Bolivia, eastern Peru, Ecuador and southern Colombia. The entities presented as karyomorph $\mathrm{A}, \mathrm{B}$ and $\mathrm{C}$ were referred to as $P$. longicaudatus based on craniodental and bacular characters, geographic distribution and karyotypic divergencies when compared with populations of $P$. brevicauda (Patton et al., 2000). However, the counterfold pattern of the cheekteeth of the specimens with karyomorphs A and B do not agree with those of the $P$. longicaudatus specimens described by Patton (1987) because they show wider variation, probably due to the inclusion of samples from a wider geographic range. As pointed out by Patton et al. (2000), more than one taxon is under the name P. brevicauda. According to the karyotypic data presented here, as well as some variation found in the morphologic qualitative characters analyzed, the same is true for $P$. longicaudatus.

Karyotypes with $2 \mathrm{n}=30, \mathrm{NF}=56$ (karyomorphs D, E and $F$ ) are similar, although karyomorph $\mathrm{E}$ is separated from $\mathrm{F}$ by the Xingu River and from karyomorph D by Tocantins River. The main difference between D and the other two forms concerns the presence of a minute metacentric chromosome (pair 14) in D which is subtelocentric in $\mathrm{E}$ and $\mathrm{F}$; and karyomorph $\mathrm{F}$ differs from $\mathrm{D}$ and $\mathrm{E}$ due to the morphology of chromosome pair 13 that is subtelocentric in D and $\mathrm{E}$ but submetacentric in $\mathrm{F}$ (Figures 6, 7 and 8). These specimens showed similar patterns in relation to the craniodental characters analyzed and were included in the guyannensis species group.

Comparison of karyomorphs D, E and F $(2 n=30$, $\mathrm{FN}=56)$ with karyomorph $\mathrm{G}(2 \mathrm{n}=30, \mathrm{FN}=52)$ suggests that pericentric inversions in chromosome pair 3 and in another small autosome should be the mechanism responsible for the difference between the fundamental numbers. Forms D, E and $\mathrm{F}$ also presented a reasonably distinct decrease in the size of their autosomes in opposition to karyomorph $G$ (Figure 9) that encompasses three large chromosomes (pairs 1,2 and 3) typically separated from the other autosomes which decrease gradually in size (pairs 4 to 14$)$.

Karyomorphs D, E and F are similar to those specimens with $2 \mathrm{n}=30, \mathrm{FN}=56$ from Pará state described as $P$. oris (Barros, 1978; Gardner and Emmons, 1984) and from several Cerrado (including localities from the geographical range of $P$. roberti) and eastern Amazon Basin specimens (Weksler et al., 2001). Weksler et al. (2001) found that phenotypic divergence among populations of $P$. oris and $P$. roberti was higher than karyotypic or genetic divergence, considering $P$. oris Thomas, 1904 as a junior synonym of $P$. roberti Thomas, 1901. We followed Weksler et al. (2001) and, based on their distribution and karyological, the speci- 
mens presenting karyomorphs D, E and $\mathrm{F}$ were identified as Proechimys roberti, a member of the guyannensis species group. Our karyomorph $\mathrm{G}$, however, is quite different from these and we suggest that it belongs to a different taxonomic entity. Besides, the C-banding seems to be species-specific, revealing two distinct groups: one including karyomorphs D, E and F as one entity and the other comprising karyomorph G. Geographical distribution corroborates this hypothesis.

Comparison of $2 \mathrm{n}=28, \mathrm{FN}=48$ (A) and $2 \mathrm{n}=30$, $\mathrm{FN}=52(\mathrm{G})$ which are found at the same locality (Usina Hidrelétrica de Samuel = locality number 11 in the map of Figure 1) revealed a high level of similarity. Chromosomes 1 to 6 are homologous in both karyotypes and 8, 9, 10, 11, 12,13 and 14 of $2 n=30$ are homologous respectively to 7 , $8,9,10,11,12,13$ of $2 \mathrm{n}=28$. One metacentric pair (pair 7) in the $2 n=30$ karyotype is not detected in $2 n=28$ and it represents the difference between both karyotypes (Figure 10).. The qualitative morphological characters analyzed agree with the karyological data in the sense that the karyomorph G specimen is part of the longicaudatus species group. Since these karyomorphs (A and G) were found in sympatry, and they belong to the same species group, we consider them as distinct taxonomic entities.

The new cytotype $(2 \mathrm{n}=44, \mathrm{NF}=52)$ was found in the same region as $P$. guyannensis and $P$. cuvieri but is a different taxonomic entity (Malcolm, 1992). No karyotype similar to this has been described until now and since we did not analyze this specimen, it was not possible to allocate it to any Proechimys species group.

Regarding the Proechimys geographical distribution five species were already detected at single localities, being actually syntopic, and may even have occupied the same burrows at different times (Patton et al., 2000; Emmons, 1982; Malcolm, 1992). We observed sympatry involving $2 \mathrm{n}=15$ and $2 \mathrm{n}=28$ (karyomorph A) in Juruena, MT, as well as $2 n=30$ (karyomorph $G$ ) and $2 n=28$ (karyomorph A) in Usina Hidrelétrica Samuel, RO. In the first case, the species were assigned to different species groups, however, in Usina Hidrelétrica Samuel, RO, they belong to the same regional unit. Karyomorph D $(2 \mathrm{n}=30)$ was observed in three localities: Estação Ecológica Uruçuí-Una, PI; Paranã and Peixe, TO; karyomorph E in two localities: Cláudia and Gaúcha do Norte, MT; and karyomorphs B, C and F in just one locality each (Figure 1).

These data indicate greater karyological variability within populations of $P$. roberti than that previously reported by Weksler et al. (2001), probably due to the inclusion of western Amazonian and eastern Cerrado populations, encompassing a large geographical area. Additionally, it shows distinct karyological entities within the longicaudatus and the goeldii species groups. Indeed, if we consider these five species (Proechimys gr. goeldii with $2 \mathrm{n}=15 ; P$. longicaudatus karyomorphs $\mathrm{A}, \mathrm{B}$ and $\mathrm{C} ; P$. roberti karyomorphs $\mathrm{C}, \mathrm{D}$ and $\mathrm{F} ; P$. gr. longicaudatus karyomorph G; and Proechimys sp. with $2 \mathrm{n}=44$ ), we are assuming a remarkable intraespecific variability in $P$. longicaudatus and $P$. roberti. On the other hand, if these karyological data are treated in a multidisciplinary context and other levels of divergence are detected, these nine karyotypic entities would provide the necessary information to corroborate the status of species within $P$. longicaudatus and $P$. roberti.

Defining species and/or species boundaries over large geographic segments has often proven extremely difficult (Patton et al., 2000) and, especially in Brazil, there are huge gaps which have yet to be filled. Patton et al. (2000) found eight species along the Juruá River, these species being based on morphological features, chromosomal data and the molecular sequences of the mitochondrial DNA (mtDNA) cytochrome- $b$ gene and emphasized that mtDNA sequences revealed that morphological data had previously been underestimated by Patton (1987). In the present paper we provide cytogenetic data on Proechimys from new Brazilian localities which may be useful in a multidisciplinary karyotypic, morphological, molecular or bio-geographic context to shed light on the evolutionary diversification of this abundant neotropical rodent genus.

\section{Acknowledgments}

We thank: Dr. Miguel T. Rodrigues, Pedro L B. Rocha, Gilson Ximenez, Vinícius Xavier da Silva, Gabriel Skuk, Dante Pavan, Jay Malcolm, Alexandra Bezerra, Flávio Rodrigues for helping in fieldwork and collecting some animals; Renata Cecília Amaro-Ghilardi and Juliana Pagnozzi for some chromosome preparations; and Cyntia Esteves and Glaciene Tomaz for technical assistance. Grants to support this study were provided by Fundação de Amparo à Pesquisa do Estado de São Paulo (FAPESP), Conselho Nacional de Desenvolvimento Científico e Tecnológico (CNPq) and Coordenação de Aperfeiçoamento de Pessoal de Nível Superior (CAPES).

\section{Appendix}

Specimens examined and karyotyped, housed at the Museu de Zoologia da Universidade de São Paulo (MZUSP and APC) and at the Museu Nacional do Rio de Janeiro $(\mathrm{MN})$ :

Proechimys gr. goeldii

Mato Grosso: Juruena, MZUSP 31924 (skin and skull).

Proechimys gr. longicaudatus

Rondônia: Usina Hidrelétrica Samuel, Jamari River, MZUSP 27396 (skin and skull).

Proechimys longicaudatus

Rondônia: Usina Hidrelétrica Samuel, Jamari River, MZUSP 27391 (skin, skull and baculum), MZUSP 27392 (skin and skull), MZUSP 27547 (skin and skull), MZUSP 27548 (skin, skull and baculum), MZUSP 27549 (skin and 
skull), MZUSP 27550 (skin and skull), MZUSP 27551 (skin, skull and baculum); Mato Grosso: Aripuanã, MZUSP 31925 (skin and skull), MZUSP 31926 (skin), MZUSP 31927 (skin and skull), MZUSP 31928 (skin and skull), MZUSP 31929 (fluid), MZUSP 31930 (fluid); Apiacás, MZUSP 31931 (fluid), MZUSP 31932 (fluid), MZUSP 31933 (fluid), MZUSP 31934 (fluid), MZUSP 31935 (fluid and baculum), MZUSP 31936 (fluid) and embryo of MZUSP 31933; Juruena, MZUSP 31937 (skin and skull), MZUSP 31938 (skin and skull), MZUSP 31939 (skin and skull); Goiás: Parque Nacional das Emas, Mineiros, MN 67246 (skin and skull) and MN 67247 (skin and skull).

\section{Proechimys roberti}

Mato Grosso: Cláudia, MZUSP 31940 (skin and skull), MZUSP 31941 (skin and skull), MZUSP 31942 (fluid), MZUSP 31943 (fluid), MZUSP 31944 (skin and skull); Gaúcha do Norte, MZUSP 31945 (skin and skull), MZUSP 31946 (skin and skull); Vila Rica, MZUSP 31947 (skin and skull), MZUSP 31948 (skin and skull); Tocantins: Paranã, MZUSP 31949 (skin and skull); Peixe, MZUSP 31950 (skin and skull), MZUSP 31951 (skin and skull), APC 828 (baculum); Piauí: Estação Ecológica de Uruçuí-Una, Bom Jesus, MZUSP 30355 (skin and skull), MZUSP 30365 (skin and skull), MZUSP 30370 (skin and skull), 30375 (skin, skull and baculum).

\section{References}

Aguilera M and Corti M (1994) Craniometric differentiation and chromosomal speciation of the genus Proechimys (Rodentia, Echimyidae). Z Säugetierkunde 59:366-377.

Aguilera M, Reig OA and Pérez-Zapata A (1995) G- and Cbanding karyotypes of spiny rats (Proechimys) of Venezuela. Revista Chilena de História Natural 68:185-196.

Barros RMS (1978) Variabilidade cromossômica em Proechimys e Oryzomys (Rodentia) do Amazonas. Tese de Doutoramento, Universidade de São Paulo, São Paulo.

da Silva MNF (1998) Four new species of spiny rats of the genus Proechimys (Rodentia, Echimyidae) from the western Amazon of Brazil. Proc Biol Soc Washington 111:436-471.

Emmons LH (1982) Ecology of Proechimys (Rodentia, Echimyidae) in south-eastern Peru. Trop Ecol 23:280-290.

Emmons LH and Feer F (1997) Neotropical Rainforest Mammals, a Field Guide. 2nd edition. Univ. Chicago Press, Chicago, $307 \mathrm{pp}$.

Gardner AL and Emmons LH (1984) Species groups in Proechimys (Rodentia, Echimyidae) as indicated by karyology and bullar morphology. J Mammal 65:10-25.

King M (1993) Species Evolution - The Role of Chromosome Change. Cambridge University Press, Cambridge, 336 pp.

Lara MC and Patton JL (2000) Evolutionary diversification of spiny rats (genus Trinomys, Rodentia, Echimyidae) in the Atlantic Forest of Brazil. Zool J Linnean Society 130:661686.
Lara MC, Patton JL and da Silva MNF (1996) The simultaneous diversification of South American echimyid rodents (Hystricognathi) based on complete cytochrome b sequences. Mol Phylogenet Evol 5:403-413.

Leal-Mesquita ERRBP (1991) Estudos citogenéticos em dez espécies de roedores brasileiros da família Echimyidae. Dissertação de Mestrado, Universidade de São Paulo, SP.

Malcolm JR (1992) Use of tooth impressions to identify and age live Proechimys guyannensis and P. cuvieri (Rodentia, Echimyidae). J Zool 227:537-546.

Moojen J (1948) Speciation in the Brazilian spiny rats (genus Proechimys, family Echimyidae). University of Kansas Publications, Museum of Natural History 1:301-406.

Patton JL and Gardner AL (1972) Notes on the systematics of Proechimys (Rodentia, Echimyidae), with emphasis on Peruvian forms. Occas Paper Museum Zoology Louisiana State University 44:1-30.

Patton JL and Rogers MA (1983) Systematic implications of non-geographic variation in the spiny rat genus Proechimys (Echimyidae). Z Säugetierkunde 48:363-370.

Patton JL (1987) Species groups of spiny rats, genus Proechimys (Rodentia, Echimyidae). Fieldiana Zoology, new series, 39:305-345.

Patton JL, da Silva MNF and Malcolm JR (2000) Mammals of the Rio Juruá: Evolutionary and ecological diversification of Amazonia. Bulletin of the American Museum of Natural History 244:1-306.

Reig OA and Useche M (1976) Diversidad cariotipica y sistematica en poblaciones Venezolanas de Proechimys (Rodentia, Echimyidae), com datos adicionales sobre poblaciones de Peru y Colombia. Acta Cient Venez 27:132-140.

Reig OA, Tranier M and Barros MA (1979) Sur l'identification chromosomique de Proechimys guyannensis (E. Geoffroy, 1803) et de Proechimys cuvieri Petter, 1978 (Rodentia, Echimyidae). Mammalia 43:501-505.

Reig OA, Aguilera M, Barros MA and Useche M (1980) Chromosomal speciation in a Rassenkries of Venezuelan spiny rats (genus Proechimys, Rodentia, Echimyidae). In: Vorontsov NN and Van Brink JM (eds) American Genetics and Evolution. Dr. W. Junk Publishers, The Hague, Netherlands, pp 291-312.

Rodrigues FHG, Silveira L, Jácomo ATA, Carmignotto AP, Bezerra AMR, Coelho DC, Garbogini H, Pagnozzi J and Hass A (2002) Composição e caracterização da fauna de mamíferos do Parque Nacional das Emas, Goiás, Brasil. Revista Brasileira de Zoologia 19:589-600.

Schweizer D (1980) Simultaneous fluorescent staining of Rbands and specific heterochromatic regions (DA/DAPI bands) in human chromosomes. Cytogenetics and Cell Genetics 27:190-193.

Voss RS, Lunde DP and Simmons NB (2001) The mammals of Paracou, French Guiana: A neotropical lowland rainforest fauna. Part 2. Nonvolant species. Bulletin of the American Museum of Natural History 263:1-236.

Weksler M, Bonvicino CR, Otazu IB and Silva Júnior JS (2001) Status of Proechimys roberti and P. oris (Rodentia, Echimyidae) from eastern Amazonia and Central Brazil. Journal of Mammalogy 82:109-122.

Woods CA (1993) Suborder Hystricognathi. In: Wilson DE and Reeder DM (eds) Mammal Species of the World. 2nd edition. Smithson. Inst. Press, Washington, DC, pp 771-806. Associate Editor: Horácio Schneider 